\title{
Giant squamous cell carcinoma of the scalp
}

\section{Soumaya Hamich', Fatima Zahra El Gaitibi', Kaoutar Znati², Meriem Meziane', Nadia Ismaili ${ }^{1}$, Laila Benzekri' ${ }^{1}$, Karima Senouci ${ }^{1}$}

\section{${ }^{1}$ Department of Dermatology, University Hospital Center Ibn Sina, Rabat, Morocco, ${ }^{2}$ Department of Histopathology,} University Hospital Center Ibn Sina, Rabat, Morocco

Corresponding author: Soumaya Hamich, MD, E-mail: hamich.soumaya@gmail.com

We report the case of a 43-year-old male with a history of pulmonary tuberculosis cured one year previously and a 25 -year-old history of smoking. The patient presented with a tumor of the scalp that had been evolving since the age of thirteen years, gradually increasing in size, neglected by the patient. An examination revealed a giant tumor of the occipital area (Fig. 1), $15 \times 8 \mathrm{~cm}$ in size, which was protruded and ulcerated, with thick, hard edges.

On biological assessment, a hemogram revealed microcytic hypochromic anemia at $2.9 \mathrm{~g} / \mathrm{dL}$. Ferritin was at $4 \mathrm{ng} / \mathrm{mL}$. HIV serology was negative. A

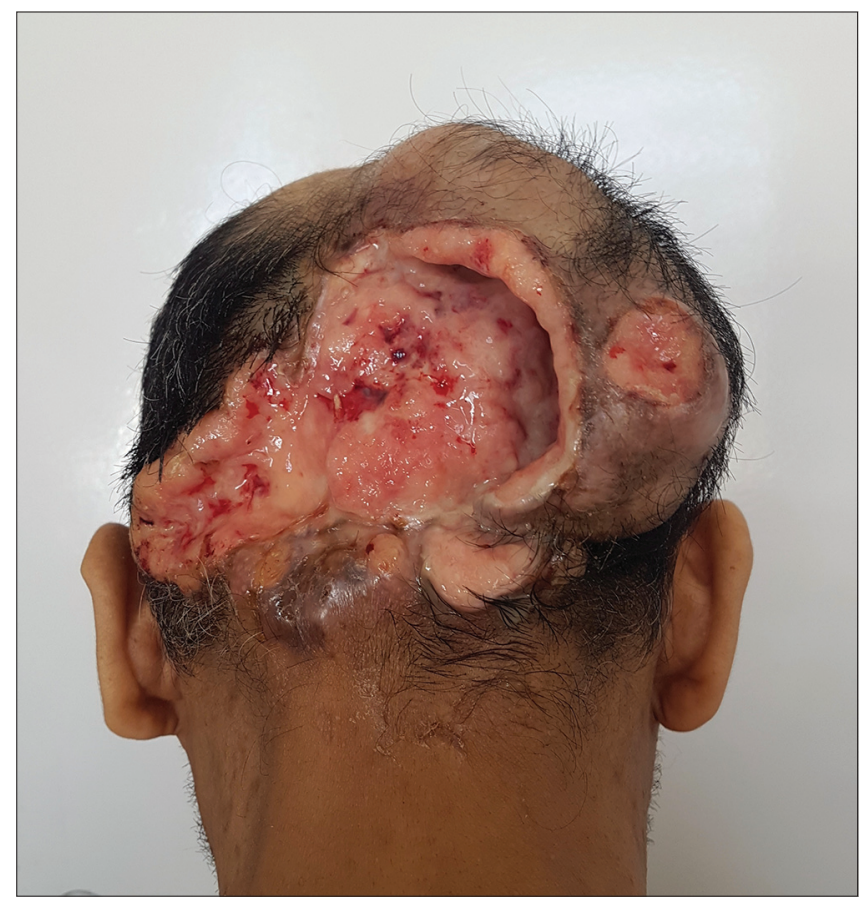

Figure 1: Protruded and ulcerated giant occipital tumor with thick, hard edges and normal peri-lesional skin. skin biopsy revealed a mature, well-differentiated, infiltrating squamous cell carcinoma (Fig. 2). A CT scan of the brain revealed a poorly limited subgalactic parietooccipital lesion process, with bone lysis and endocranial extension and invasion of the upper longitudinal sinus. Ultrasonography of the lymph node area revealed bilateral axillary and inguinal adenopathies with an infracentimetric fatty hilum. The immediate management was to transfuse the patient with three red blood cells. Control hemoglobin was $7.7 \mathrm{~g} / \mathrm{dl}$. The patient, then, received external radiotherapy but was lost to follow-up.

Squamous cell carcinoma is the second most common skin cancer [1], occurring in elderly patients with a clear phototype on sun-exposed areas. Its frequency is increasing and correlates with sun exposure [1]. It may reach enormous sizes if neglected and not treated in

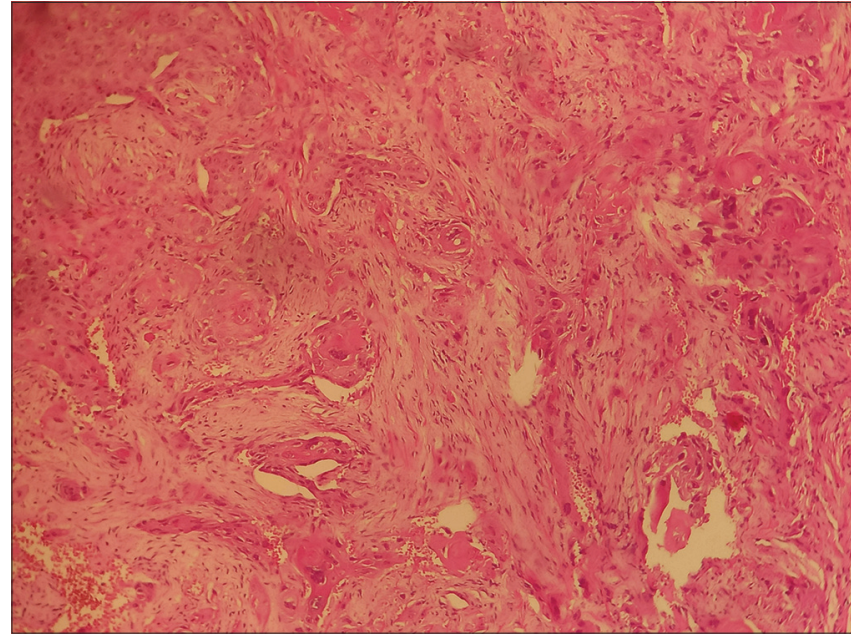

Figure 2: Well-differentiated and mature squamous cell carcinoma on an anatomopathological image of the dermis.

\footnotetext{
How to cite this article: Hamich S, El Gaitibi FZ, Znati K, Meziane M, Ismaili N, Benzekri L, Senouci K. Giant squamous cell carcinoma of the scalp. Our Dermatol Online. 2022;13(1):99-100.

Submission: 28.02.2021; Acceptance: 07.05.2021

DOI: 10.7241 /ourd.20221.25
} 
its early stages. The most common causes of a delayed diagnosis are low socioeconomic status, poor personal hygiene, and fear of the diagnosis and of its possible consequences [2].

Giant carcinomas are defined by a diameter exceeding $5 \mathrm{~cm}$ [3]. They pose a higher risk of complication and mortality. The invasiveness of these tumors depends on the size, anatomical location, and histological subtype. Their treatment is difficult because, even with extensive surgical removal, recurrence and metastasis are frequent [3].

\section{Consent}

The examination of the patient was conducted according to the principles of the Declaration of Helsinki.

The authors certify that they have obtained all appropriate patient consent forms, in which the patients gave their consent for images and other clinical information to be included in the journal. The patients understand that their names and initials will not be published and due effort will be made to conceal their identity, but that anonymity cannot be guaranteed.

\section{REFERENCES}

1. Combalia A, Carrera C. Squamous cell carcinoma: An update on diagnosis and treatment. Dermatol Pract Concept. 2020;10:e2020066.

2. Ricci F, Paradisi A, Fossati B, Mancini M, Curatolo P, Guerriero C, et al. Giant neglected squamous cell carcinoma of the skin. Dermatol Ther. 2015;28:230-4.

3. Misiakos P.E, Damaskou V, Koumarianou A, Gouloumi AR, Patapis A, Zavras N, et al. A giant squamous cell carcinoma of the skin of the thoracic wall: A case report and review of the literature. J Med Case Rep. 2017;11:136.

Copyright by Soumaya Hamich, et al. This is an open access article distributed under the terms of the Creative Commons Attribution License, which permits unrestricted use, distribution, and reproduction in any medium, provided the original author and source are credited.

Source of Support: Nil, Conflict of Interest: None declared. 